\title{
New name for SARS-CoV-2 variants
}

\section{Introduction}

On May 31, 2021, the World Health Organization (WHO) announced new, simple, easy-to-say and remember names for the most worrying variants of SARS-CoV-2, using letters from the Greek alphabet. These designations were chosen after extensive consultation and review of potential naming systems. WHO convened a group of experts from around the world, including experts in the nomenclature and taxonomic naming of viruses, researchers, and national authorities. ${ }^{1}$

Scientific names can be difficult to pronounce and remember, and are prone to misinformation. As a result, people often name variants based on where they are detected, which is stigmatizing and discriminatory. To avoid this and simplify public communications, WHO encourages national authorities, the media and others; adopt these new names.

According to the WHO, it classifies the variants into two types, according to their impact on public health: variants of concern and of interest.

Abbreviations: WHO, World Health Organization; INS, National Institute of Health; CDC, Centers for Disease Control and Prevention

\section{Variants of concern}

These SARS-CoV-2 variants have been shown to be associated with one or more of the following changes, therefore they are of global public health significance:

a) Increase in its transmissibility or generates a change in the epidemiology of COVID-19; or

b) Increase in virulence or change in the clinical presentation of the disease; or
Volume 6 Issue 4 - 202।

\author{
Luis Figueroa Montes ${ }^{1,2,3}$ \\ 'Servicio de Patología Clínica, Hospital III Suárez Angamos, \\ EsSalud. Lima, Perú \\ ${ }^{2}$ Asociación Médica Peruana de Patología Clínica. Lima, Perú \\ ${ }^{3}$ Medicina del Laboratorio Lima-Perú
}

Correspondence: Luis Figueroa Montes, Department of Clinical Pathology, Hospital III Suarez Angamos, Lima, Perú, Tel+5196676/40I, Email patologoclinico@gmail.com

Received:June 16,2021 | Published: December 29, 2021

c) Decrease in the effectiveness of social and public health measures or of available diagnoses, vaccines and treatments. Figure 1

\section{Variants of interest}

These variants have mutations with established phenotypic implications, and they have been identified as causing community transmission, with multiple cases, or have been detected in several countries. $^{2}$

For example, the delta variant of COVID-19, first seen in India, could become the dominant variant in the United States, as the country continues its efforts to vaccinate the population, the infectious disease expert warned. from the country Dr. Anthony Fauci: "The delta variant now makes up more than $6 \%$ of sequential cases in the US It is a situation like the one they had in the UK and we cannot allow that to happen here," he warned. ${ }^{3}$

\begin{tabular}{|c|c|c|c|c|c|c|}
\hline WHO label & $\begin{array}{l}\text { Pango } \\
\text { lineage. }\end{array}$ & $\begin{array}{l}\text { GISAID } \\
\text { clade }\end{array}$ & Nextstrain clade & $\begin{array}{l}\text { Additional amino } \\
\text { acid } \\
\text { changes monitored }^{\circ}\end{array}$ & $\begin{array}{l}\text { Earliest } \\
\text { documented } \\
\text { samples }\end{array}$ & Date of designation \\
\hline Alpha & B.1.1.7 & GRY & 201 (V1) & $\begin{array}{l}+S: 484 K \\
+S: 452 R\end{array}$ & $\begin{array}{l}\text { United } \\
\text { Kingdom, } \\
\text { Sep-2020 }\end{array}$ & 18-Dec-2020 \\
\hline Beta & B.1.351 & GH/501Y.V2 & $20 \mathrm{H}(\mathrm{V} 2)$ & +S:L18F & $\begin{array}{l}\text { South Africa, } \\
\text { May-2020 }\end{array}$ & 18-Dec-2020 \\
\hline Gamma & P.1 & GR/501Y.V3 & $20 \mathrm{~J}(\mathrm{~V} 3)$ & $+\mathrm{S}: 681 \mathrm{H}$ & $\begin{array}{l}\text { Brazil, } \\
\text { Nov-2020 }\end{array}$ & 11-Jan-2021 \\
\hline Delta & B.1.617.2 & G/478K.V1 & $21 \mathrm{~A}, 21 \mathrm{I}, 21 \mathrm{~J}$ & $\begin{array}{l}+\mathrm{S}: 417 \mathrm{~N} \\
+\mathrm{S}: 484 \mathrm{~K}\end{array}$ & $\begin{array}{l}\text { India, } \\
\text { Oct-2020 }\end{array}$ & $\begin{array}{l}\text { VOI: 4-Apr-2021 } \\
\text { VOC: } 11-M a y-2021\end{array}$ \\
\hline Omicron* & B.1.1.529 & GRA & $\begin{array}{l}21 \mathrm{~K}, 21 \mathrm{~L} \\
21 \mathrm{M}\end{array}$ & $+\mathrm{S}: \mathrm{R} 346 \mathrm{~K}$ & $\begin{array}{l}\text { Multiple } \\
\text { countries, } \\
\text { Nov-2021 }\end{array}$ & $\begin{array}{l}\text { VUM: } 24-N o v-2021 \\
\text { VOC: } 26-N o v-2021\end{array}$ \\
\hline
\end{tabular}

Figure I New designation of variants (2). 
Peru has just overcome a second catastrophic wave and a future scenario of the third with a delta variant would be alarming. The National Institute of Health (INS) is investigating a possible case of the Indian variant of COVID-19 in Peru. This was reported by the head of the institution, Víctor Suárez, before the Special Commission for Monitoring Emergencies and COVID-19 Disaster Risk Management of Congress. "Apparently we have a specific case of the Indian variant. We are doing epidemiological research together with the CDC (Centers for Disease Control and Prevention) to confirm this case, "he added. ${ }^{4}$

It should be noted that the World Health Organization (WHO) is studying the evolution of variant C.37, popularly known as the "Andean variant", to see if it should be classified as of "interest" or "concern". He was recognized today by the branch of the health agency in the American continent, the Pan American Health Organization. Although he maintained that there is still not enough evidence to include the variant in the classification, he also clarified that any country has autonomy to declare a variant of the coronavirus as worrying based on the information it has on the evolution of the virus. ${ }^{5}$

Let's hope that new variants of concern do not continue to appear, because they undoubtedly affect the global vaccination process with a significant decrease in the effectiveness of vaccines and public health interventions.

\section{Acknowledgments}

None.

\section{Conflicts of interest}

The author states there are no conflicts of interest.

\section{Funding}

None.

\section{References}

1. WHO announces simple, easy-to-say labels for SARS-CoV-2 Variants of Interest and Concern. EEUU; 2021.

2. SARS-CoV-2 Variants of Concern and Variants of Interest. EEUU; 2021.

3. VOA. Variante de COVID-19 detectada en India podría convertirse en dominante en EEUU. Venezuela; 2021.

4. RPP. INS investiga un posible caso de la variante india de la COVID-19 en el Perú. Perú; 2021.

5. Ñanduti. Variante andina del coronavirus: La OMS reconoció que estudia su avance en el mundo Perú. 2021. 